\title{
殺虫剂残渣の生物試験法に関する研究
}

第 1 報 Knock down 效果を変動させる処理面における

微量の Moisture について

\section{Studies on the biological assay of insecticide residues \\ (I) Effect of insecticide residue in the presence of minute moisture}

\author{
井上 義 郷* \\ Yoshisato Inoue
}

\section{緒言}

防疫用殺虫剂を実地に使用する一つの大きな分野は残 留処理であるから，防疫薬剂の効力評価には，残渣を用 いる接触試験法が大きな意義を持つてくる．この場合の 試験条件としては，殺虫剂を虫体に直接適用寸る一連の 試験法と異り，あらかじめ撒布された薬剤の，処理面に おける行動と接触時の虫の行動の二つが，特に重要な問 題となってくる.

薬剂の行動に関する研究の一つとしては, 処理面の理 化学性と残渣の持続性の関係について詳細な研究があ り, また, 接触時の虫と薬片の反応現象に関する温湿度 の影響についての報告も多いが，処理面に扝ける薬剤の 行動そのものに関与する温湿度の影響や，更にこれと処 理面の物理性との関連をとらえた組織的な研究は殆んど みられないように思われる。また一方, 現在, わが国で 広く行われている, 残渣の試験法には, 未だ再現性に多 くの問題があるように思われ，まず，それらの問題点を 明らかにする必要が認められる.

そこで，そのような観点から，残渣を用いる試験法の 改良を目的としてこの研究に着手した. なお，この研究 の一部は日本衛生動物学会, 第 13 回大会で講演した.

本文に入るに先だち, 常々御指導を戴いている朝比奈 正二郎博士ならびに安富和男博士に謝意を表する。なお 供試虫の飼育の労をとられた久保田和美氏に感謝する。

\section{$\mathrm{KT}_{50}$ 值を変動させる要因の追求}

同一供試虫を用い, 或る一つの薬剤について, その適 用条件ならびに実験時の温湿度条件を厳密に一定とした

* 国立予防衛生研究所衛生昆虫部

Department of Medical Entomology, National Institute of Health, Tokyo
場合でも, 時に $\mathrm{KT}_{50}$ 值の評価が大きく変動することが ある. 例えば一度実験に用いた残渣を再び続けて使用し た場合には，初回に得られた結果の $\mathrm{KT}_{50}$ 值よりも，む しろ, 再使用の場合のそれが小さくなる傾向があり, 更 に同一残渣を続けて数回にわたり使用すると, $\mathrm{KT}_{50}$ 值 は図1のように，実験の繰返しの変動とは別に，それを

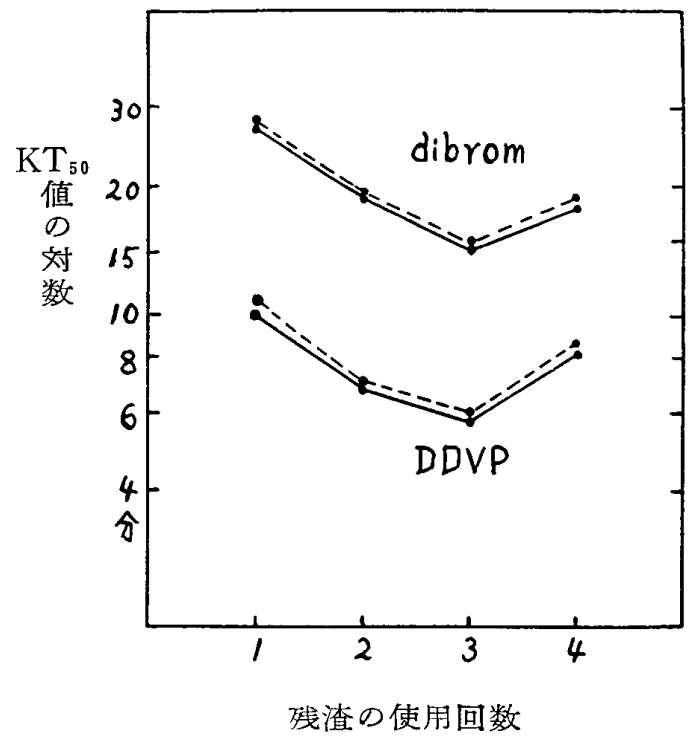

図 1 残渣の再使用々 $\mathrm{KT}_{50}$ 值の変動する傾向

註実線と破線の間隔は繰返しの場合の变動

越えて大きく, 或る定つた秩序をむつて変動することが ある. また, 特に残効性の試験においては, 残渣の age と $\mathrm{KT}_{50}$ 值とは必ずしも平行関係を示さず，古い残渣が より高い効果を示し，逆転現象のみられる場合もある. そこで本報では，まずそのような現象の問題点を検討す ることにした。

供試虫：ここに報告する実験には総て,イエバエ成 虫を指示昆虫として用い, その 30 頭 (性比 1 対 1 ) 宛を 1 群として取扱つた. なお, 供試イエバエ Musca dome- 
stica vicina Macq. (高槻系統) は当研究空の $28^{\circ} \mathrm{C} の$ 恒温飼育室で豆腐粕培基（豆腐粕 $1 \mathrm{~kg}$ にエビオス $35 \mathrm{~g}$ 混入）を用いて 飼育羽化させた, 羽化後 $4 \sim 7$ 日目の成 虫である。

供試残渣：それぞれの実験目的によつて, 各種殺虫 剂の乳剂, 油剂或いはアセトン溶液を用い, その処理面 としては濾紙を主体に，時にはガラス板や心゙ニヤ板を供 試した．何れの実験でも撒布量は総て $1 \mathrm{~m}^{2}$ 当り $50 \mathrm{cc}$ 宛々なし，それらを $25^{\circ}$ C, R.H. $40 \pm 5 \%$ 比較的湿度 の低、恒温室内にそのまま放置し, 所定時間後の乾燥残 渣を供した。

接触試験法： 総て径 $9 \mathrm{~cm}$, 高さ $2 \mathrm{~cm}$ のシャーレを 用いる継続接触法を採用し，得られた時間致落下仰転率 回帰直線から, 主として $\mathrm{KT}_{50}$ 值を概算で求め, それに 基いて各種の問題点の考察を行つた. なお, 接触試験は 何れも前記恒温室内で実施した。

実験 $\mathbf{A}$ ：図 1 に示されているように，同一残渣にお いても初回の試験結果と再使用のそれとの間で $\mathrm{KT}_{50}$ 值 に大きな変動がみられることから，まず，残渣面に供試 虫の 30 頭宛を事前にそれぞれ 1 分間および 5 分間はわ せ，その残渣を直ちに実験に用いた場合と，そのままの 残渣を用いた場合との間で $\mathrm{KT}_{50}$ 值の変動を比較検討し た。なお，この実験には Dibrom 乳剂の $0.5 \%$ 希釈液の 24 時間後濾紙画残渣を用いた。

表 $1 \mathrm{KT}_{50}$ 值の变動因の検討

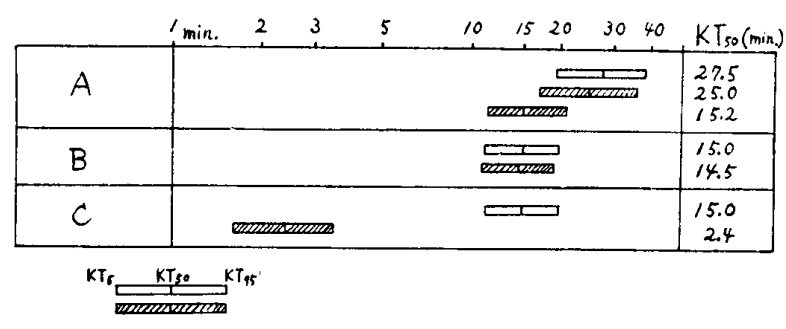

註 白は対照で事前の处理を瓜どこさない場合 の結果を示す。

A …事前に八ェをはわせた残渣面を供試 した場合.上から順に対照, 1 分及 び 5 分閏はわせた場合の結果を示す。

B …⼀走の方法一摩擦した残椬面を供武 した場合.

C…呼気を与えた残渣を供試した場合.

結果は表 1，Aのようであり，事前に虫をはわせた場 合が，しかもその時間の長いものほど $\mathrm{KT}_{50}$ 值が小とな る傾向認めた. 以上の結果から二つの仮定を導いて次 の実験B㧍よびCを行つた。

実験 B： まず，供試虫が沬い廻ることによつて，残 渣面が攪乱され，その結果，処理面の内部に吸収されて いた薬剂の blooming が助長され, 表面の有効作用薬舅
が変化し，それが $\mathrm{KT}_{50}$ 值に反映するのではないか，と 云ら推定の下に, 残渣上に重量 $100 \mathrm{~g}$ のもの采せた清 潔な鰓紙を重ね，それを静かに2 往復させることによつ て残渣面を一定の状態で摩擦したものを実験に供した。 この奏験には DDVP 乳剂の $0.5 \%$ 希釈液の 24 時間後 濾紙面残渣を用いた.

実験結果は表 1，Bのようであり，事前の処理をほど こさない残渣と比べて $\mathrm{KT}_{50}$ 值には殆んど変動汢認めら れなかつた。

実験 C： 接触時にシャーレ内に閉じ込められた供試 虫の代謝で，その中は当然多湿となり，それと関連して 残渣の moisture も変化し，それが処理面における薬剤 の行動に何等かの意味で関係し, 表面に存在する有効作 用薬量が変動寸るのではなかろらか，その仮定に基き， 口もとで 10 秒間，残渣面に呼気を与え，直ちにその残 渣について実験を試みた。供試残渣は実験Bの場合と同 様である。

この実験結果から， $\mathrm{KT}_{50}$ 值を大きく変動させる一つ の要因は, 残渣の moisture であることが明らかとなつ た(表 1 , 実験 C参照).このように乾燥残渣に呼気を与 えた程度の微量の moisture の変化で $\mathrm{KT}_{50}$ 值が大きく 影響されることは，実験の操作上，特に注目されなけれ ばならない。

\section{残渣の moisture の量と $\mathrm{KT}_{50}$ 值との関係}

実験 D: 残渣の微量の moisture によつて $\mathrm{KT}_{50}$ 值 が大さく変動する現象が実験的に確認されたので，その 量と $\mathrm{KT}_{50}$ 值との関係を事前に残渣面に moisture 与えることによつて比較検討した。ここでは残渣の moisture の絶対值, 寸なわち, 含水量の測定は行わず, 便宜的に, 水 $0.5 \mathrm{cc}$ を含ませた濾紙を敷いた径 $9 \mathrm{~cm}$, 高さ $2 \mathrm{~cm}$ のシャーレで供試残渣面を覆い，間接的な力 法で微量の moisture を与え, その量は覆う時間を変え ることによつて相対值で示した．そして值ちにそれらの 残渣を用いて実験を行い，それぞれの $\mathrm{KT}_{50}$ 值を求め た.

実験結果は表 2 のに示した。また，横軸に moisture の量を示す相対湿潤指数 (R.M.I) の対数をとり, 縦軸に は $\mathrm{KT}_{50}$ 值 (対数) をとつて雨者の関係を示したものが 网2である。

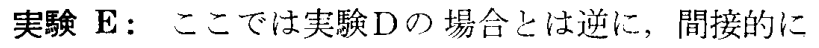
moisture 老与える為の水量を変えて, 作用させる時間は 一定の 10 分間となし, 全く同様の実験を行つた。なお, 結果は表 $20 \mathrm{E}$ 打よび図 2 に示した.

実験 $\mathrm{D}, \mathrm{E}$ の両者の結果を考察すると，図 2 からも明 らかなように, 両者とも与えた moisture の量, すなわ 
表 2 Moisture の量的变化と $\mathrm{KT}_{50}$ 值の 変動する傾向

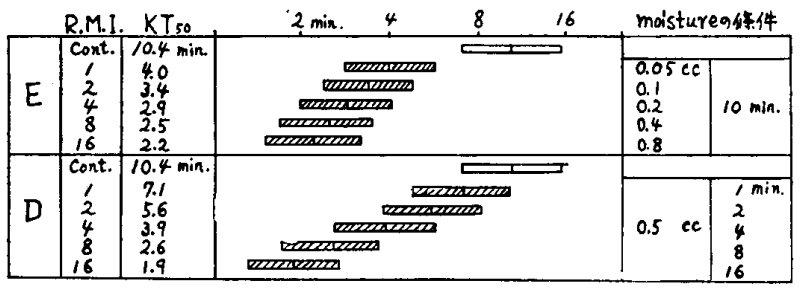

註 1. R.M.I. …Relative Moisture Index

2. moisture の条件…残渣面に關接的に与 えた水量と時間を示す。
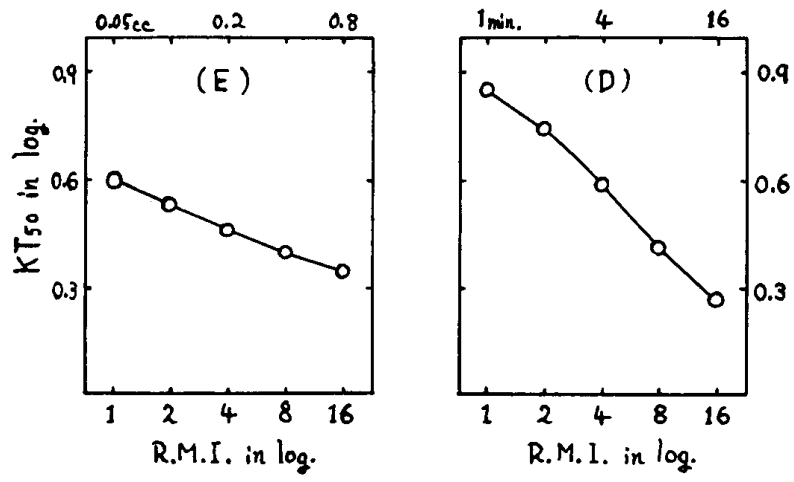

四 2 R.M.I. と $\mathrm{KT}_{50}$ 值との関係

ち，相対湿潤指数 (R.M.I) と $\mathrm{KT}_{50}$ 值とは逆の相関を 示し，ほぼ直線に近い関倸が認められた。実験 $\mathrm{E} の$ 結果 からそれらの関係を計算值で示すと次のようになる.

$\log \mathrm{Y}=2.00657-0.33548 \mathrm{X} \pm 0.06339$

$\mathrm{Sy}= \pm 0.1158 \mathrm{~min} . \mathrm{r}=-0.899$

なお，図 2 亿おいて，Dと $\mathrm{E} の$ 場合で直線の勾配が異 ることは, moisture の与え方が両者で異つているためと 思われ，湿潤能率の違いがそこに示されたものと考え る.

\section{殺虫剂の種類と moisture の影響}

実験 F : これまでの実験には主として DDVP の残 渣を供試したが，殺虫片の有効成分の種類が 異れば, moisture の影響性がどのように変化するか，その傾向を 明らかにするための検討を試みた。

この実験に用いた殺虫剤の種類は, DDVP, Dibrom, diazinon, Korlan, Baytex, Dipterex, lindane の各乳剂で ある，それらの何れも $0.5 \%$ 希棌液の濾紙面残渣を，す でに記した条件の恒温室内に 24 時間ならびに 15 日間そ のまま放置し，それらの残渣に実験 $\mathrm{D}$ と同様の方法で一 定量の moisture (この場合, 水 $0.5 \mathrm{cc}$, 作用時間 8 分間) を与え，直ちに実験に供試した。そして得られた $\mathrm{KT}_{50}$ 值とそのまま供試した dry 残渣のそれとの比率の逆数,
すなわち $1 / \mathrm{W} / \mathrm{D}$ を求め，その值を moisture の影響に よる $\mathrm{KT}_{50}$ 值の变動指数となし，それに基いて相対的に 比較考察した.

表 3 に示す実験結果の変動指数（F.I.）を通覧する と，moistureを与えた場合には，何れの殺虫剤もその影 響を受け，そのまま供試した残渣の場合に比較して， 一般に $\mathrm{KT}_{50}$ 值は小となる傾向が認められた. 特に 顕著にその影響を受ける，変動指数の大きい殺虫剂は

表 3 各種殺虫剂残渣と moisture の影響

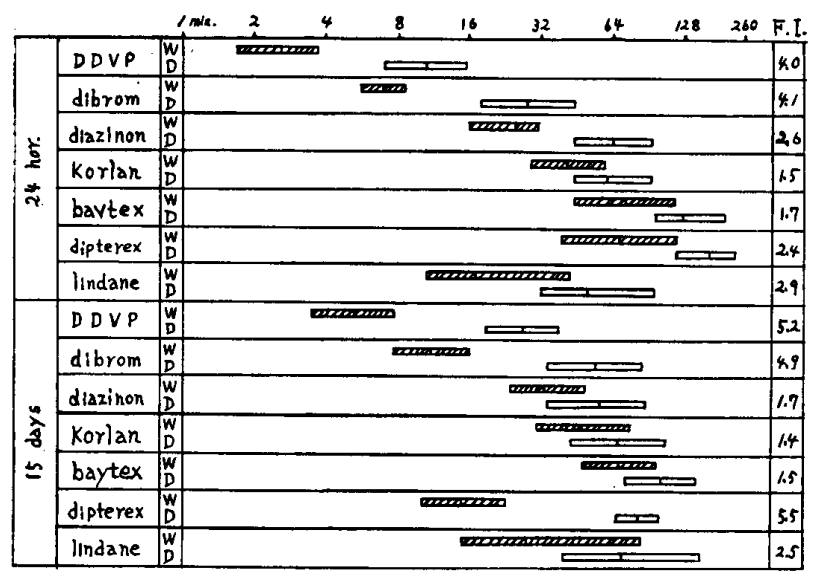

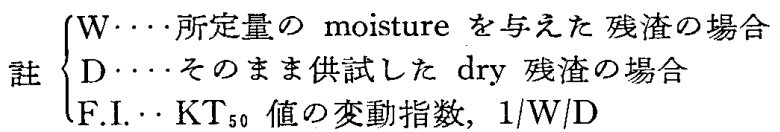

DDVP および Dibrom であり, lindane がこれに次ぎ, そして，それらがいずれも比較的蒸気圧の高い殺蝓で ある事は, 薬剤の処理面に扔ける行動を追求する上に特 に注目される。

次にそれぞれの殺虫剤に関する $\mathrm{KT}_{50}$ 值の変動指数 を，24時間後残渣の場合と 15 日間そのまま放置した， いわゆる残效性の test に用いる残渣の場合で 比較する と，一般的には両者で平行関係が認められ顕著な差異は ないと云えるが，特に注目すべきことは Dipterex の場 合である. 24 時間後残渣の場合は変動指数は 2.4 で比 較的小さいが，15日後残渣のそれは 5.5 に増大し, DDVP のそれ之同等となつてきており，そこには平行 関係沬認められない，この事は両者で化学構造が近似 し, 分解移行の点を考え合せると極めて興味深く考察さ れる。

\section{製剤形態ならびに処理面の物理性と moisture の影響}

実験 $\mathrm{G}$ ：これまでの実験には総て乳剂の残渣が供試 されていたが，それ以外の剤形，すなわち，油剤やアセ トン溶液の場合においても同様の傾向が認められるかど らかの検討を行った，供試薬郕としては最も顕著に moi- 
表 4 㶡形及び処理面の種類と moisture の影響

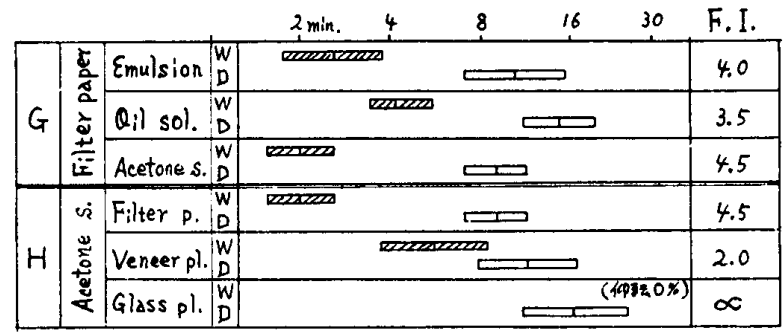

sture の影響を受ける DDVP を選び，その $0.3 \%$ 油剂 および $0.5 \%$ ケトン溶液の 24 時間後濾紙面残渣を供 試した。その他の実験方法は実験 $\mathrm{F} の$ 場合と全く同様で ある・

表 4，G の結果から明らかなように, 乳剤, 油剤, ア セトン溶液の間では，KT $\mathrm{KT}_{50}$ 值の変動指数は特に顕著な 差異を示さず，したがつて，製剤の形態とは特に関係な く,やはり，主剤そのものが問題となることが確認され た.

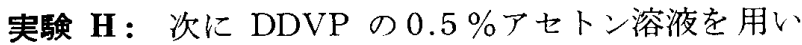
て，処理面の物理性と moisture の影響との関係を検討 した。供試処理面としては，吸収性の高い滤紙と非吸収 性のガラス板およびその中間的な物理性と考えられるべ 二ヤ板を選定し，その他は実験 $\mathrm{G} の$ 方法に隻じて実験を 行つた.

表 4 のHから明らかなように, 薬剤の吸収性が高い処 理面ほど， moisture の影響は顕著で， $\mathrm{KT}_{50}$ 值は小とな る傾向を示し，その変動指数は濾紙の場合が最も大き く，ベニヤ板がこれに次ぐ. なお，非吸収性のガラス板 では，moistureを与えた場合，これまでの傾向とは逆に $\mathrm{KT}_{50}$ 值は，むしろ大となる傾向を示し，特に DDVP を用いたこの実験では残渣の消失が認められ，KT $\mathrm{K}_{50}$ 值 は得られなかつた.この事とさきの蒸気圧の問題とは処 理面における薬剤の行動に対寸る moisture の意義を説 明する上に極めて重要な現象と考える.

なおう，本報では残渣に対して実験的に所定量の moisture を，しかも短時間に与えて， $\mathrm{KT}_{50}$ 值の変動する傾 向を検討したが， moisture は環境の湿度と平衡関係を示 すものと考えられ，また，処理面における薬剤の行動は もともと動的に把握すべきものであるから, 関係湿度と 更にそれらにさらされる時間との関連性においてとらえ ることが必要である. その点と moisture の意義に関し ては次報で詳細に考察することとし, 今回は以上の実験 結果を報告するに止めたい。

\section{総 括}

1. 殺虫剂の残渣を用いる接触試験においては, 時に knock down 効果の評価が繰返しの変動を越えて大きく
乱れることがある.この点をイエバエ成虫を指示昆虫と して検討した，その結果， $\mathrm{KT}_{50}$ 值の大きく変動する一 つの要因は, 残渣の微量の moisture であることが実験 的に明らかとなつた。

2. 残渣の moisture の量と $\mathrm{KT}_{50}$ 值とは, DDVP 乳剤の濾紙面残渣を用いた実験によれば，逆の相関を示 しほほほ值線的な関係が認められた。

3. そのような moisture の影響が，他の 殺虫剂の残 渣においてもみられるかどうかを，7種類の殺虫剤の乳 剤について検討したところ，一般的にはいずれの場合に もその影響が認められ，特に顕著に $\mathrm{KT}_{50}$ 值が変動する のは, 比較的蒸気圧の高い DDVP および Dibrom の残 渣であり, lindane がこれにつぐことを知つた。

更に乳剤以外の剂形，すなわち，油剤やアセトン溶液 の場合の残渣でも，同様の傾向がみられるかどうかの検 討を試みたところ，剂形とは特に関係なく，やはり殺虫 成分そのものの種類が問題となることを確認した.

4. 以上の実験は総て 濾紙面残渣で行つたものであ るが，物理性の異る他の処理面の場合に，そのような moisture の影響がどのように異るかを，DDVP のアセ トン溶液を用いて実験した。

Moisture の影響は, 吸収性の高い滤紙面残渣の場合 が最も顕著で，心゙ニヤ板の場合がこれに次ぎ，非吸収性 のガラス板では moisture はマイナスに作用し，この場 合はむしろ, 残渣の消失する傾向が認められた. そして この現象は処理面における薬剤の行動を考える上に注目 される.

なお，処理面における薬剤の行動と moisture の意義 ならびに環境の湿度との関連性などについては次報で報 告する.

\section{参考交献}

1) Pradhan, S. (1949): Bull. ent. Res. 40:431. 2) Glynne Jones, G. D. and Edwards, R. A. (1952): Bull. ent. Res. 43 : 67. - 3) Hewlett, P. S. and Gostick, K. G. (1955) : Ann. Appl. Biol. 43 : 213. -4) Collins, W. E. and King, H. L. (1953) : J. Econ. Ent. 46 : 51. - 5) Potter, C. and Gillham, E. M. (1946) : Ann. Appl. Biol. 33 : 142. -6) Hadway, A. B. and Barlow, F. (1952): Bull. ent. Res. 43 : 281. - 7) Dovidson, G. (1953) : Bull. ent. Res. 41 : 231. - 8) Hadway, A. B. (1950): Bull. ent. Res. : 41: 63. - 9) 井上義郷 (1956) : 衛生動物, 7 (1)：43. - 10）鈴木猛，遠山輝彥 (1957)：防虫科学, $22(3): 283$. - - 11) 平社俊之助 (1958)：街生動物, $9(3): 191$. 


\section{Summary}

It has been known, as an actual phenomenon, that during a contact-test on an insecticide film the $\mathrm{KT}_{50}$ values (the measurement of insecticidal potency to test insects) often unexpectedly fluctuated. Using house flies an investigation was attempted on this phenomenon.

It was experimentally confirmed that test insects are more susceptible to insecticide residues when its treated surface contains a minute amount of moisture.

The relationship between the $\mathrm{KT}_{50}$ values and the amount of the moisture showed an inverse correlation. Such an instability of knock down effect due to the moisture, is the most evident in both cases of DDVP and Dibrom regardless the formulation of the insecticide when applied on absorptive materials such as filter paper or veneer plate. If applied on a glass plate, however, similar effect was not recognized.

\title{
Nankor による八工駆除実験
}

\author{
Field test of fly control using Nankor \\ (0,0-dimethyl 0-2, 4, 5-trichlorophenyl phosphorothioate)
}

武 衛和 雄1) 福 原 佳 春2)

Kazuo Buéi and Yoshiharu Fukuhara

近年低毒性の有機燐酸エステル系殺虫郕が急速な進歩 をし，衛生害虫駆除の面にもひろく使用されるようにな り，駆除効果の上から高く評価されているものが少な くないわれわれはまえに malathion 製剂の野外実験 を通じて八エの成虫, 幼虫に対する駆除効果を検討し, その適用範囲のひろいことをしつた。今回は最近米国 カナダ等において広く使用されている Nankor $(0,0$ dimethyl 0-2,4,5-trichlorophenyl phosphorothioate)製剂 により大阪府下の一農村において前回に準じた方法で八 エ駆除を目的としたフィルド実験を行なつたので報告す 万.

この実験にあたつては箕面市役所ならびに地域住民の 方々の御協力を仰いだ．また薬剤の提供その他の御協力 頂いた日綿実業株式会社，旭工業株式会社に対しあつく お礼を申しあげる。

\section{実験地区の概況}

実験地として選んだ 箕面市新家地区は戸数 40 戸，人 口約 200 名の純農村で, 周辺は小丘陵と水田に囲まれた
1）大阪府立公衆衛生研究所
Public Health Research Institute, Osaka-fu, Osaka
2) 大阪府池田保健所
Ikeda Health Center, Osaka Prefecture

独立集落を形成している，薬剤散布を行なうまえにその 対象となるべき八エの発生源や棲息場所について詳細な 調査をした結果は表 1 のようであつた。

また比較対照地区として 新家地区より約 $100 \mathrm{~m}$ 東に 隣接し，かつ独立集落よりなる小野原地区(戸数 245 戸, 人口約 1,100 名)を選んだ。部落の環境は実験地区と比 較的よく似通つた農村で，この地区では実験期間中を通 じて薬剤の散布や環境の整備は殆んど行なわれなかつ た.

表 1 実験地区口瑗境概況（薬昘潵布地区）

\begin{tabular}{|c|c|c|c|c|c|}
\hline & 家屋 & 便池 & 牛小含 & 鶏小合 & 納屋 \\
\hline 散 布 対 管 数 & 40 & 40 & 23 & 25 & 35 \\
\hline 総 面 積 $\mathrm{m}^{2}$ & 4331.3 & 50.2 & 99.1 & 361.4 & 1519.7 \\
\hline 一戸当りの面積 $\mathrm{m}^{2}$ & 108.3 & 1.3 & 4.3 & 14.4 & 43.4 \\
\hline
\end{tabular}

\section{実験方法}

実験に使用した Nankor*は $0.5 \%$ 油剂，10\%乳剂， $1 \%$ 粉剂の 3 種類である。

* Nankor は 0,0-dimethyl 0-2,4,5-trichlorophenyl phosphorothioate $66.2 \%$ を含有するので, 液郕又は 粉剤にするさいは有效成分が $100 \%$ となるよ 製した。 